\title{
INSURANCE UNDER THE FEDERAL INCOME TAX*
}

\author{
BY WILLIAM VICKREY $\dagger$
}

SINCE to the layman insurance is a forbiddingly complicated business, it is not surprising to find that under the Internal Revenue Code the treatment of the various aspects of insurance has hardly adhered to a logical principle. Owing in part to the timidity of legislators in dealing with a matter which they did not clearly understand, and perhaps in part to effective lobbying by the insurance interests, insurance has in general been less heavily taxed than other types of enterprise, sources of income, and forms of property.

Two distinct phases of the insurance taxation problem are the treatment of insurance proceeds and premiums in the income tax return of the individual or business insured, and the treatment of insurance companies and their stockholders under the corporation and individual income taxes. While the tax on insurance companies has received the greatest amount of attention from the legislature, it is in the treatment accorded the insured that the violation of economic principles and canons of taxation is most patent and the language of the statute and regulations most vagute.

\section{INDIVIDUAL INCOME TAX}

Fire and Casualty Insurance

One of the least complicated aspects of the problem is the treatment of fire and casualty insurance in computing the income tax of the policyholder. The most straightforward case of this type is the insurance of business property. Under the present federal law premiums paid are deductible as a business expense ${ }^{\prime}$ losses covered by insurance may not be deducted, ${ }^{2}$ while indemnity payments made to the insured are not counted as income. ${ }^{3}$ This treatment is satisfactory when the loss which would be deductible if no insurance had been purchased is the same as the insurance recovered. When, however, there is a discrepancy between the two figures, some adjustment is necessary. Actually the regulations require the proceeds of an insurance policy covering loss of income from property to be included as income to the same extent as the income they

* The opinions expressed herein represent the personal views of the author, and do not necessarily reflect those of the Treasury Department.

† Senior Economist, U. S. Treasury Department, Division of Tax Research; now in Civilian Public Service Camp, Powellville, Md.

1. U. S. Treas. Reg. 103, $\$ 19.23$ (a) -1 .

2. U. S. Treas. Reg. 103, $\$ 19.23$ (e) $-1,19.23(\mathrm{f})-1$.

3. No specific statement to this effect could be found in the law or regulations, but the implication is fairly direct. 
replace. ${ }^{4}$ And the regulations appear to imply that if the amount recovered is not immediately reinvested in similar property as a replacement, it must be treated as a realization of income and any recovery in excess of the "adjusted basis" taxed as a capital gain." On the whole it would be simpler and more consistent to permit deduction of all losses, whether or not covered by insurance, and to require all insurance proceeds to be included in gross income. In this way several ambiguities and uncertainties would be avoided, particularly those arising when there is some doubt as to whether a claim will be paid in full by an insurance company.

Premiums paid for insurance against the loss of consumer durables, such as insurance of an owner-occupied dwelling against fire, may not be deducted under the present law, ${ }^{6}$ and this rule appears to be sound. Not only is the premium a purely personal expense connected with services to the taxpayer, but if such a deduction were permitted, the existing discrimination against lessees would be increased, for although rent ordinarily includes the cost of insurance, a lessee can make no deduction for it. ${ }^{7}$ The difficulty with this treatment is that the person who does not insure and who suffers a loss is permitted to deduct the loss. while the insured is allowed no deduction from his income. ${ }^{8}$ Thus in providing against an insurable calamity which occurs on the average once every ten years, $A$ who insures and pays premium of $\$ 100$ every year for ten years gets no deduction on his income tax return, while $B$ who does not insure but pays out $\$ 1,000$ every ten years to make good the damage is able to talse this loss as a deduction from his income. This is at least one case in which. despite the much protested deterrent effect of taxes on risk-taking in new business ventures, the law encourages the taxpayer to take risks.

In order to avoid entirely discriminations between the insurer $A$, the non-insurer $B$, and the lessee $C$, either $B$ must be denied the privilege of deducting the loss, or an amount roughly corresponding to the premium for insurance against this loss must be included in his taxable income each year. Inclusion of such a hypothetical insurance premium would create a difficult administrative problem, particularly since it would be

4. U. S. Treas. Reg. 103, $\$ \$ 19.22$ (a) $-7, \llbracket 3$ (crop insurance), 19.112( $($ ) $-1, \llbracket 4$ (in a section dealing with capital gains from involuntary conversions).

5. U. S. Treas. Reg. $103, \$ 19.112(\mathrm{f})$. The adjusted basis is to be determined according to section 113, INT. REv. CODE (1939) (unless otherwise indicated, seetions hereafter cited will be the latest applicable sections of the basic tax system in either the Internal Revenue Code or subsequent amendments).

6. U. S. Treas. Reg. 103, § 19.24-1.

7. For example, the home owner may deduct both mortgage interest and property taxes while the renter may make no deduction, even though a substantial part of his rent is used by the landlord to cover these items.

8. U. S. Treas. Reg. 103, $\$ 19.23(\mathrm{e})-1 \mathrm{c}$. It is not specifically so stated, but presumably where the insurance covers only a part of the loss, the part not compensated for would be deductible. 
appropriate to include only the pure risk part of the premium and to exclude any loading for expenses or profit. Because of the large variety of losses possible, it would probably be necessary, in order to determine which premiums should be included in the taxpayer's income, to require him to declare in advance which losses he would want to deduct should he suffer them in the future. The impracticability of such a solution is evident. Further, the line between the accidental destruction of consumer goods and destruction in the normal course of use may be extremely tenuous. For example, the writer has frequently risked the theft of property more or less deliberately for the sake of greater convenience in its use. Thus an allowance for such losses may permit deductions which are of doubtful justifiability. The present law certainly tempts the wealthy to refrain from insuring and even to neglect to protect property from risk of loss. For in the event of loss the income tax deduction will absorb such a large part of it that protection may cost more than it is worth to the taxpayer as an individual, even though for the community as a whole it may be highly desirable.

Permitting no deduction for losses may produce hard cases among those with relatively small incomes, yet for persons subject to high rates of tax the present practice produces too severe a discrimination against those taking precaution against risk. As a reasonable compromise, deduction of losses could be allowed only for normal tax purposes, or when, as at present, the surtax extends to all taxpayers, a tax credit could be provided at a rate equal to the sum of the normal tax and first bracket surtax rates. This solution would be administratively simple, would relieve the hardship cases and would reduce the more extreme discriminations to tolerable levels.

Accident and health insurance and employees' compensation present a different problem. At present benefits received from this type of insurance are specifically excluded from gross income. ${ }^{0}$ So far as these benefits cover only medical and hospital expenses connected with accident or illness, such insurance is on a par with other forms of casualty insurance. But the benefits also extend to replacing in some measure income lost through enforced idleness resulting from accident or sickness. This part of a benefit should rightly be included in income just as benefits paid under a "use and occupancy" insurance contract are included in the case of a business. To avoid the necessity of apportioning insurance benefits, it may be desirable, however, to require the entire amount of the benefit to be included in income, and to permit medical expenses above a certain normal level to be deducted separately. ${ }^{10}$

9. Section 22(b) (5).

10. Pub. L. No. 753, 77th Cong., 2d Sess. (Oct. 21, 1942) (hereafter cited as Pub. L. No. 753) inserts subsection $23(\mathrm{x})$ in the Internal Revenue Code to provide for the deduction of the excess of medical expenses over 5 per cent of net income, with a limit on 
If benefits are included in income, accident and health insurance, premiums should be deductible in order to prevent discrimination in favor of the non-insurer who puts aside savings for a rainy day and need not report as income his drawings on these sarings in time of need. Unlike the case of the lessee and the home-owner, in which deduction of premiums would have introduced a discrimination. permitting this deductiun would eliminate rather than produce a differential between the person who purchases insurance directly and the one for whom it is purchased by a third party.

The question may well arise at this point whether some distinction should not be made between the pure risk portion of the premium which is used to pay benefits and the part required for defraying overhead expenses and paying profits. This latter part represents actual resources which are used in providing the service to the policylolder, as distinguished from the mere transfer of funds from some policyholders to others in accordance with their relative needs as measured by the occurrence or non-occurrence of some disaster. In principle, the appropriate treatment of this portion of the premium appears to depend upon whether the activity giving rise to the occasion for insurance is one of obtaining income or spending it. When under two different modes of earning a livelihood the amount of insurance required to provide a certain amount of security and closeness of timing between income and need differs, the difference in overhead insurance expenses should not be permitted to produce a difference in tax. On the other hand, if the overhead insurance expenses are incurred because the taxpayer chooses to spend his income in a way which involves a risk it is deemed worthwhile to insure against, rather than in a way involving no such risk, the expenses are personal and should be included in income. For the sake of simplicity, however, it will probably be desirable to ignore such fine distinctions and treat the overhead element of the premiums in the same way as the risk element, thus avoiding any necessity for an apportionment of the premium which would greatly confuse the taxpayer.

Another consideration which enters into the treatment of casualty insurance in the individual return is the fact that certain forms of insurance are often purchased for long periods in advance. The tax avoidance made possible by such purchases may be seen in its most extreme

the amount of the deduction of $\$ 2,500$ for a joint or head of family return and $\$ 1,250$ for other returns. Section 22 (b) (5) is also amended by this section so as to imply that accident and health insurance proceeds are to be included in incurme up to the amount of this deduction.

To prevent abuses similar to those arising in the case of losses to personal property, it would be advisable to make this allowance in the form of a tax credit at a rate equal to the combined first bracket rate. If this is done the maximum limit on the allowance might be increased or removed entirely. 
form in the so-called perpetual plan of writing insurance. Under this plan the insured pays an initial premium deposit several times greater than the normal annual premium, so that the interest earned from the investment of this deposit by the company will be large enough to pay losses and expenses. In mutual companies interest from the invested deposit is usually sufficient to provide, in addition, for the payment of substantial annual dividends to the policyholders out of the excess of investment income over losses and expenses. On the termination of the policy the premium is refunded to the insured. This is a very sound method of writing insurance, for it creates an extremely large fund from which conflagration or disaster losses may be met, and it reduces the expense of annual renewal and premium collection. ${ }^{11}$

In modern times the method has acquired the added advantage of affording the policyholders a substantial tax saving. For example, $A$ and $B$ may each have a $\$ 1,000$ bond bearing $\$ 30$ a year interest. $A$ uses this interest to pay the annual premium on an ordinary fire insurance policy on his house. $B$, on the other hand, sells his bond and with the proceeds pays the initial premium deposit on a perpetual type insurance policy. $A$ must pay a tax on the $\$ 30$ interest, but $B$ under present law has no tax to pay on the insurance coverage which he gets as a direct return in kind on his investment of $\$ 1,000$ in the original premium deposit. A similar but less striking discrimination occurs when insurance is paid for in advance for say three or five years and the premium is, or at least should be, reduced to allow for interest which accrues on it before it is needed to pay losses and expenses. The proper remedy, of course, is to require the interest to be included in the income of the policyholder.

In the case of stock companies the law may well specify the rate of interest to be used in computing the amount of income to be so inclucled, since variations among companies in the rate of return on investments tend to affect the return to the stockholder rather than the premium charged the policyholder. As to mutual companies, where variations in the rate of return on investments may affect dividends paid to the policyholder, it would seem appropriate, in principle at least. to require a report to each policyholder of his share of the interest actually earned (plus an allowance at a statutory rate for earnings of capital invested directly in insurance plant and working capital) and to include this share in his taxable income. In practice, however, this procedure would involve diffculties. Thus specification of an arbitrary rate of interest would seem advisable in this case also, for it would reduce the burden of compliance and administration and would at the same time be reasonably accurate.

11. This method is the one used by the oldest insurance company in the United States, The Philadelphia Contributionship for the Insurance of Houses from Loss by Fire. Despite its advantages, it has not achieved widespread coverage, owing in part to the difficulty for most people of putting up the large initial premium deposit. 
In any erent, in order to avoid multiplying picayune adjustments to income, it may be desirable to include interest on premiums in taxable income only when premiums are paid for more than one year in advance.

In the case of business insurance, whether this interest is a factor to be taken into account depends primarily on whether the cost of insurance is accounted for on a cash or on an accrual basis. When a strictly cash basis of accounting is used and the premium deposit is deducted as a cost in the year in which it is made, perpetual insurance results in a postponement of the time for reporting as income an amount equal to the premium deposit. The gain from such a postponement is equal to the interest on the tax, and so the levying of a tax on the interest on the premium would just offset the advantage. Most concerns, however, report income more nearly on an accrual than on a cash accounting basis, and in the case of perpetual insurance and insurance of the "factory mutual" type, ${ }^{12}$ accrual accounting is almost always required. When accrual accounting is employed, the income is reflected in the proper periods, and no avoidance results from large premium deposits. There would appear, therefore, to be little occasion for adding interest on premiums to the income of business policyholders.

The treatment of interest on premium deposits is clusely related to the treatment of "dividends" (also frequently termed "sarings," "profits" or "prenium deposits") returned to policyholders. When the cost of insurance purchased constitutes a business expense, no problem arises, for it is of no moment whether the item of dividends is treated as income in its own right or merely as a reduction in a deductible cost item; the net income will be the same in either case. But where the premium is not deductible, as in the insurance of consumer durables, the treatment does make a difference, and the problem raised is a rather difficult one. The regulations provide that dividends "which may be credited aggainst the current premium" are not taxable. ${ }^{13}$ But since there is no annual premium against which dividends on perpetual policies may be credited, this exclusion does not apply to them.

The whole problem is in fact but one aspect of the general problem of the treatment of coöperatives and their patronage dividends. If $A, a$ member of a coöp, purchases goods for $\$ 100$, and receives a $\$ 10$ dividend at the end of the year, should this dividend or any part of it be included in his income? The law and regulations are silent on the point, and it appears that such dividends are not included. But $A$ is obviously better off than $B$ who purchases the same goods at a regular store for $\$ 100$ and

12. The "factory mutual" companies insure primarily large factory risks, and require an initial premium deposit many times the ordinary annual premium, but less than the perpetual premium deposit-returning at the expiration of the policy 80 per cent or more of the deposit, depending on the duration of the coverage.

13. U. S. Treas. Reg. 103, $\$ 19.22$ (a) -12 . 
receives no dividend. Hence it would appear equitable to require $A$ to pay a higher income tax. On the other hand, what about $C$ who goes to a cut rate store and buys the same goods for $\$ 90$, with somewhat less service, or $D$ who is a more expert shopper and manages to get both goods and service for $\$ 90$ ? No easy solution to the problem is available, but the balance of considerations seems to be on the side of treating the dividend as an individual economy in consumption which it would be unwise to tax. This conclusion is particularly true in view of the possibility of having to deal with $E$ who is a member of a coöp which charges $\$ 110$ and pays a dividend of $\$ 20$. Most mutual life insurance policyholders are actually in this position. In order to tax such a dividend, it wotld be necessary to undertake the extremely difficult task of apportioning it between the return of an initial overcharge and the distribution of a net saving or "profit." Possibly some part of the $\$ 10$ dividend received by $A$ may be attributed to the fact that he previously purchased shares in the coöp, and thus made a capital investment upon which he received a return roughly equivalent to the interest he might have received had he invested the same sum in other ways. Mutual insurance company dividends can best be dealt with by including as a separate item in income that part of them which is interest on a capital sum. Otherwise it seems on the whole that dividends of mutual insurance companies should not be included in the income of the taxpayer.

\section{Life Insurance}

The proper treatment of life insurance is an even more complex problem than the treatment of casualty insurance. Life insurance is not simply the spreading of a risk, but includes a very substantial element of saving. Premiums paid for it can be broken down into three elements : amounts paid for current insurance protection; savings used to build up a reserve to supplement premiums in the later years, which in themselves will be insufficient to provide the full insurance coverage; and loading charges for overhead expenses. The proceeds of life insurance are also a combination of three elements: the return of the accumulated savings portions of the premiums; interest earned on these accumulations; and the amount of pure insurance which was necessary to fill out the face of the policy. ${ }^{14}$

14. The bewildering variety of insurance policies results from combining the savings and pure insurance elements in varying proportions. At one extreme a rencwable term policy calls for a constant amount of insurance and no savings, with a constantly rising premium, while at the other end a single premium endowment includes a large amount of savings and a small and decreasing amount of insurance. Ranging in between in approximate order are convertible term, "modified premium," whole life, limited payment life, endowment, limited payment endowment, single premium life. The breakdown of 
In principle, at least the savings part of the life insurance contract should obviously be treated as any other form of savings; that is, the interest should be included in the income of the policylolder as it accrues, but proceeds representing return of principal should not be included. An analogy to a savings account is particularly apt in that life insurance companies, except in the first few years of their policies, ordinarily make

premiums and proceeds into their elements varies over the life of the policy, the portion of the premium going for immediate protection usually rising and the part going into the reserve usually falling over the life of the policy (in the later years of some policies, particularly limited payment policies, the cost of insurance protection for the current year exceeds the premium and must be defrayed in part by drawing on the accumulated savings). The parts of the proceeds attributable to the savings and interest elements rise and the part which constitutes pure insurance falls over the life of the policy. The following table shows how this breakdown varies for a typical policy:

Analysis of premiums and procecds.

$\$ 1,000$ whole life non-participating nolicy issucd at age 40.

Commissioners' 1941 Standard Ordinary mortality table, 3 per cent interest. Initial expense: $\$ 20.70$ per $\$ 1,000$ face value plus 65 per cent of gross premium. Renewal expense: $\$ 2.00$ per $\$ 1,000$ face value.

Subsequen $\ldots \ldots \ldots \ldots \ldots \ldots \ldots \ldots \ldots . . . \ldots 27.15 \quad \$ 38.35 \quad \$-11.20$

\begin{tabular}{|c|c|c|c|c|c|c|c|c|c|}
\hline \multirow[b]{3}{*}{ 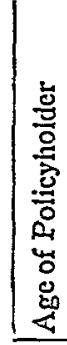 } & \multirow[b]{3}{*}{ 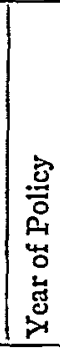 } & \multirow{2}{*}{\multicolumn{2}{|c|}{$\begin{array}{l}\text { Disposition of } \\
\text { Net Premium } \\
\end{array}$}} & \multirow[b]{3}{*}{ 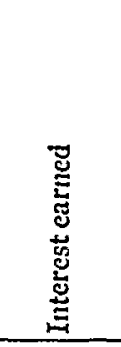 } & \multicolumn{4}{|c|}{ Composition of Proceeds } & \multirow[b]{3}{*}{ 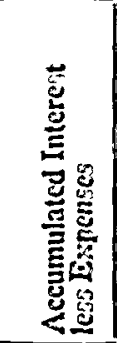 } \\
\hline & & & & & \multicolumn{3}{|c|}{ Reserve at end of year } & \multirow[b]{2}{*}{ 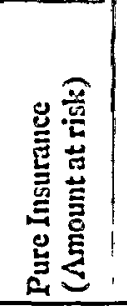 } & \\
\hline & & 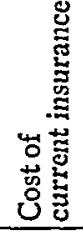 & 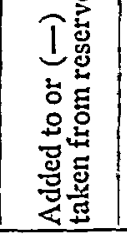 & & 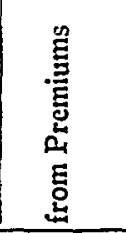 & 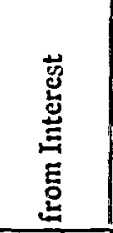 & $\begin{array}{l}\overrightarrow{5} \\
\text { 웅 }\end{array}$ & & \\
\hline & & $\$ 6.28$ & $\$-17.48$ & $\$-.34$ & $\$-17.48$ & $5-.34$ & $5-17.82$ & $\$ 1017.82$ & -38.69 \\
\hline 41 & 2 & 6.58 & 18.57 & .22 & 1.09 & -.12 & .97 & 999.03 & -40.23 \\
\hline 42 & 3 & 6.88 & 18.27 & .78 & 19.36 & .66 & 20.02 & 979.98 & -41.69 \\
\hline $\begin{array}{ll}73 \\
44\end{array}$ & $\frac{4}{5}$ & 7.22 & $\begin{array}{l}17.93 \\
17.59\end{array}$ & 1.30 & $\begin{array}{l}37.29 \\
54.85\end{array}$ & 2.02 & 39.31 & 960.69 & -42.33 \\
\hline 49 & 10 & 9.62 & 15.53 & 4.92 & 136.88 & 22.52 & 159.40 & 840.60 & -33.83 \\
\hline 54 & 15 & 12.27 & 12.88 & 8.03 & 206.84 & 56.42 & 263.26 & & -9.93 \\
\hline 59 & $\begin{array}{l}20 \\
25\end{array}$ & $\begin{array}{l}15.54 \\
19.40\end{array}$ & 9.61 & $\begin{array}{l}11.16 \\
14.24\end{array}$ & 261. & 105.96 & $\begin{array}{l}367 \\
469\end{array}$ & & $\begin{array}{l}29.61 \\
8469\end{array}$ \\
\hline 69 & 30 & 23.78 & 1.37 & 17.16 & 314.20 & 251.07 & $\begin{array}{l}409 \\
565\end{array}$ & 434 & 154.72 \\
\hline 74 & 35 & 28.46 & -3.31 & 19.8 & 307. & 344.96 & & & 238.61 \\
\hline 79 & 40 & 33.22 & -8.07 & 22.16 & 276.24 & 451.22 & 727 & & 334.87 \\
\hline $\begin{array}{lll}84 \\
89\end{array}$ & 50 & $\begin{array}{l}3 / .02 \\
41.57\end{array}$ & $\begin{array}{l}-12.57 \\
-16.42\end{array}$ & $\begin{array}{l}24.12 \\
25.71\end{array}$ & $\begin{array}{l}222.25 \\
147.46\end{array}$ & 693.55 & $\begin{array}{l}790 \\
841\end{array}$ & 209 & $\begin{array}{l}441.70 \\
55720\end{array}$ \\
\hline 94 & 55 & 41.50 & -16.65 & 27.06 & 61.19 & $\$ 26.14$ & 887.33 & 112.67 & 679.79 \\
\hline 95 & 56 & 39.45 & -14.30 & 27.37 & 46.89 & 853.51 & 900.40 & 99.69 & 705.16 \\
\hline $\begin{array}{l}96 \\
97\end{array}$ & $\begin{array}{l}57 \\
58\end{array}$ & $\begin{array}{l}37.77 \\
37.71\end{array}$ & $\begin{array}{l}-12.62 \\
-12.56\end{array}$ & $\begin{array}{l}27.77 \\
28.22\end{array}$ & $\begin{array}{l}34.27 \\
21.72\end{array}$ & $\begin{array}{l}851.25 \\
909.50\end{array}$ & 931. & 68.49 & $\begin{array}{l}7.50 .95 \\
757.15\end{array}$ \\
\hline 08 & 59 & 39.33 & -14.18 & 28.69 & 7.53 & 938.19 & 945.72 & 54.2 & 783.24 \\
\hline & 60 & & 25.15 & 29.13 & & 967.32 & 1000.00 & 0.00 & $\$ 10.97$ \\
\hline
\end{tabular}


available to policyholders on demand a large part of the interest earned in the form of cash surrender and loan values. ${ }^{15}$

The proper treatment of the pure insurance portion of the contract is somewhat less clear. The balance of considerations, however, indicates that this portion should be considered as a replacement of income lost through the death of the insured, rather than as compensation for loss of property or for abnormal expenses incurred, as are proceeds from a fire insurance contract. ${ }^{16}$ Thus it would be proper to treat it in the same way as the proceeds from crop or accident and health insurance, that is, to permit the premiums to be deducted and to require the proceeds to be included in gross income.

The portion of the premium used for overhead expenses and profit should be treated as a deductible item also, for that part composed of purely investment expenses is analogous to brokerage fees or other investment expenses of the individual, while underwriting expenses proper are the result of a type of insurance which is not ordinarily related in any direct way to the consumption outlays of the individual.

Therefore, the correct way to treat life insurance would be to permit deduction from income of that part of the insurance premium used to pay for current protection, but not of that part which is accumulated as a savings deposit or reserve; to include in the policyholder's income the net interest earned on this reserve as it accrues; and to include in the income of the beneficiary that part of the benefit which consists of insurance proper but not that part which is paid from the reserve and consists

15. Cash and loan values are usually computed from the "reserve" on the policy, which in turn is a computation of what the accumulation of savings portions of premiums and interest thereon would be on the basis of an arbitrary assumption as to the net premium available to the company after allowing for expenses. The cash values in the early years of the policy are less than this reserve by an amount somewhat inaptly termed a "surrender charge" which is intended to allow for the costs of writing the policy. Under the present regulations of most states, this charge may not exceed $\$ 25$ per $\$ 1,000$ face value of policy. After an initial period of, typically, from ten to twenty years, the surrender charge is dropped and the surrender value is equal to the full reserve. It must be noted, however, that new methods of computing minimum surrender values have been proposed by the National Association of Insurance Commissioners (December, 1942) and have been embodied in bills which have already been introduced in legislatures of several of the more important insurance states. These new methods give a surrender value not necessarily related to the reserve; they are to be mandatory, however, only on policics issued after 1945.

16. While some part of the proceeds may be used to defray funeral expenses, this is ordinarily not the primary purpose of life insurance taken out by those subject to the income tax. Even to the extent used for such funeral expenses, life insurance is hardly to be classed with insurance of a home against fire, for funeral outlays can be varied according to taste and must be borne sooner or later by all while the loss imposed by a fire is definite and occurs only to a few. 
of the savings of the policyholder and the accumulated interest already taxed to him. When the proceeds are paid in a single lump sum, the taxable pure insurance part could legitimately be spread over a period corresponding to the remaining productive period of the insured had he lived. In this way it would be possible to avoid concentration of income in a single year merely because the future earning power of the insured has become capitalized through the payment of the policy. For the same reasons stated in the discussion of casualty insurance, it would in principle be appropriate to use a statutory rate of interest in computing the interest portion when stock companies are involved; and in the case of mutual companies, the actual rates of return obtained by them.

In the aggregate, under such a method of taxation, the amount of premiums deductible as paying for current protection would approximately offset the amount of proceeds includible as pure insurance. The net aggregate amount added to taxable income through life insurance would thus be approximately equal to the interest received by life insurance companies on the investment of their reserves less their overhead expenses. In contrast to this rather large amount that should theoretically he taxable. very little income received through the medium of life insurance is taxed under the present federal law. While no part of life insurance premiums is deductible in computing net income, ${ }^{17}$ proceeds of pulicies paid by reason of the death of the insured are specifically exempt from income $\operatorname{tax}, i^{18}$ and of proceeds obtained through the surrender or maturity of the policy during the lifetime of the insured, only the excess over the entire amount of premiums paid is taxable. ${ }^{19}$ In most of the usual forms of life insurance, the cost of the pure insurance protection which the insured enjoys during the life of the policy exceeds the interest on the reserve, so that the proceeds available to a living policyholder are almust always less than the amounts paid in and there is no taxable income. Noreuver, even in the rare case where some taxable income does exist, it is always much less than the amount of interest earned, and because of the infrequency of such cases the income is often overlooked and not reported.

Thus life insurance is unduly favored under the incume tax, particularly those forms with the greatest savings and tax-free interest elements. By this tax advantage individuals are artificially induced to accumulate their savings in the form of life insurance reserves rather than by separate investment. The situation is in some measure analogous to the caste of the perpetual casualty policy in that interest on the reserves or on the premium deposit is never taxed when it can be considered as used to provide current insurance protection. This farorable treatment is alsu

17. U. S. Treas. Reg. 103, § 19.24-1.

18. U. S. Treas. Reg. 103, $\$ 19.22$ (b) (1) -1 .

19. U. S. Treas. Reg. 103, §19.22(b) (2)-1. 
comparable to the complete exemption granted capital gains accrued at the death of the taxpayer, in that the accumulated interest portion of a death claim is not taxed, even to the extent that it exceeds the cost of the protection furnished. This unwarranted advantage is the more serious because there is very little limitation on the amount of insurance which a healthy person of large means can carry. Since by virtue of favorable tax treatment there may be an attractive probability that the net return from this investment will be greater than that obtainable through ordinary channels, insurance may thus be purchased not only for actual protection but as a speculative investment. ${ }^{20}$

Correction of this situation is not easy. A theoretical apportionment of premiums and proceeds between expenses, investment and insurance would require not only an apportionment of expenses between the investment and insurance functions of the company but actuarial calculations involving assumed mortality tables, future rates of interest in invested funds, and future renewal expenses. In the case of stock companies a wholly arbitrary allocation of the stockholders' profits between savings on mortality, savings in expenses, and excess investment income would also be necessary. In any case the taxpayer could not possibly make the separation himself, and no simple rule of thumb is available to permit a reasonably close approximation. The apportionment would have to be done by the insurance company and the policyholder notified of the amount to be deducted from or added to his income on account of his

20. Single premium policies, on which the reserves and interest earnings are relatively high, have proven a fertile field for tax avoidance that has been little cultivated by taxpayers only because tax exempt bonds have offered a means of obtaining a similar tax reduction which is less cumbersome and less burdened with overhead expenses. In its most extreme manifestations this avoidance has taken the form of borrowing on onc such single premium insurance policy in order to take out another similar policy, and repeating the process almost indefinitely. By this means the taxpayer is able to obtain a large immediate deduction for interest paid, while he may expect to be taxed on the interest earned on the policy reserves only partially and much later if at all. This process not only produces an inequity in taxation, but involves a waste of resources through needlessly multiplying the overhead involved in the writing of such insurance. Faced with a demand to do something, however hastily, about the more flagrant cases of this practice, Congress included in the Revenue Act of 1942 a provision that interest paid on indebtedness incurred to purchase insurance contracts on which "substantially all the premiums are paid within a period of four years from the date on which the contract is purchased" would not be allowed as a deduction. Pub. L. No. 753, §130. It was generally expected that this provision would prove even less effective than has the parallel provision denying a deduction for interest paid on indebtedness incurred to carry tax exempt bonds, U. S. Treas Reg. 103, $\S 19.23$ (b) -1, since not only is it difficult to determine for what purpose indebtedness is incurred or continued, but there remain many varieties of insurance suitable for such avoidance that are not covered at all by this provision, such as 10-payment life and endowment policies. 
life insurance. ${ }^{21}$ With the large and almost bewildering variety of policies which are now issued and the number of modifications possible through the use of dividends to purchase additions to a policy, the amount of work involved in making this apportionment would be a considerable burden on the companies. The work could be somewhat decreased by limiting this reporting to policies of $\$ 1,000$ or over, for the number of small ("industrial") policies in the hands of income taxpayers is probably not great; and since such policies usually carry a substantially heavier loading for overhead expense than the larger ("ordinary") ones, they would not as a rule be attractive as a deliberate means of tax avoidance. But even then the clerical work involved would still be a heary burden.

Some further simplification of the computations could be achieved by treating the pure insurance portion of the contract as property insurance rather than income insurance, and accordingly permitting no deduction of premiums and excluding this part of the proceeds from income. Although this procedure would not change the aggregate tax base or open the door to deliberate avoidance, it would operate in a slightly inequitable manner. For example, a widow who lives on insurance proceeds which were designed to replace the earnings of her husband had he lived would pay a smaller tax than a wife whose husband is still providing the income directly. But it is not likely that a discrimination of this lind would be generally regarded as a serious evil.

21. It might be thought that these computations are at least in part already made for other purposes. But actually they are seldom made for individual policies, and the basis for such computations as are made is so completely unrealistic that it would have to be done over for tax purposes. The reserves as reported to state insurance commissioners are in almost all cases computed on the basis of the "American Experience" table of mortality, based on data of almost a century ago, in which the mortality shown at ages 20 to 40 is as much as three times that shown by modern tables. These reserves are moreover computed on the "net premium" basis, that is, on the assumption that the company will receive in the future not the premium stipulated in the policy less a reasonable collection expense, but what the theoretical net premium should have been according to the obsolete mortality table. The result is that the reserves recorded for individual policies are sometimes too large and sometimes too small, but almost never correct.

This artificial computation is not merely an immaterial accounting convention intended only to assure solvency of the company as a whole. Since surrender values are based on the reserves, they frequently bear little relation to the equity of the policyholder in his policy. With mutual companies the diserepancy can be and frequently is corrected by suitable formulae for the distribution of dividends, but with the non-participating policies of stock companies this possibility is lacking and the pulicyliolder who surrenders during the early years of the policy is often heavily penalized. However, this situation may soon be considerably ameliorated by pending legislation. See nute 15 sispro. In addition to providing more equitable surrender values, the reserve computatiun wuld $b a$ put on a more realistic basis. But even after this legislation is in full force (which will take many years) reserves would still be considerably overestimated through the use of a mortality table that, while immeasurably better than the "American Experience" table, still substantially overstates actual expected mortality. 
Moreover, this treatment would enhance the effectiveness of a given amount of insurance. For example, if a given individual $A$ and his beneficiary $B$ are both subject to a 50 per cent tax rate, $A$ under the property insurance treatment would be in approximately the same position with $\$ 10,000$ worth of term insurance as he would be with $\$ 20,000$ of the same insurance under the income insurance treatment. In the latter case the net cost of insurance is cut in half by the deduction of premiums from the tax base, and proceeds are cut in half by the tax on them. On the other hand, since few persons carry life insurance to the point where the beneficiaries are subject to as high a rate of tax as the insurer, the tax burden would probably be somewhat greater under the property insurance treatment than under the income insurance treatment.

If the departure from principle involved in treating life insurance as property rather than income insurance were acceded to, it would only be necessary to compute the interest on the reserve less the expenses of the company to determine the amount to be included in the income of the policyholder. A reasonably close approximation to the desired figure could be obtained by applying an interest rate to the surrender value of the policy, which is usually printed in a table on the back. The fact that in the early years of the policy this value is less than the full reserve would result in an approximate allowance for heavy initial expenses. Yet it would be surprising indeed if any large number of taxpayers would or could make this computation for themselves without mistakes, particularly since many policies have dividend additions or other modifications which would have to be taken into account. Therefore it would probably be necessary to impose on insurance companies the not inconsiderable task of computing this interest and reporting it to the taxpayers. For all practical purposes it would probably be sufficient to make no report of any deduction in cases where the expenses exceed the interest, and start reporting only when the accumulated interest begins to exceed accumulated expenses. Such reporting would thus be automatically eliminated with respect to most industrial policies, and during the first few years of most ordinary policies the necessity for reporting would be obviated. The amounts of interest to be reported subsequently would be more substantial, and annual reporting would be relatively less burdensome.

If even this procedure entailed too great a clerical burden on the companies, the work might possibly be reduced still further by requiring the amount of accumulated interest to be reported in a single lump sum at the time of realization on the policy through loan, surrender, maturity, or death. ${ }^{22}$ This device would, however, result in the lumping, in a single

22. On some policies that have been in effect for a long period, accumulated interest less expenses may total to more than the surrender value or even more than the face of 
year, income which should properly be spread out over a period of years. The postponement of the tax which would have accrued had the interest been reported currently would work to the advantage of the taxpayer to the extent of the interest on the tax so postponed. but lumping of income might, except in cases of abnormally low income from other suturces in the year of realization, work to his disadvantage by pushing his incume into a higher surtax bracket. ${ }^{23}$ On the whole, however, such a solution might not be too bad as a stopgap measure. It is probably as much as can be expected short of a shift to either a spendings tax ${ }^{24}$ or to a comprehensive averaging plan of assessment.. ${ }^{25}$ Even with such lump sum reporting it might still be necessary to exempt industrial policies.

Annuities issued by life insurance companies present a prublem that is the obverse of insurance. In a single premium annuity the annuitant pays the company a fixed capital sum and receives a fixed annual payment as long as he lives. This annual payment is composed of three parts: the return of a portion of the capital sum deposited, the interest on the balance of this sum, and an amount representing the premium paid by the life insurance company to cover the escheat of the balance of the capital to the company should the annuitant die during the ycar. This premium portion may be regarded as the individual's share of a distribution among

the policy. To avoid requiring the taxpayer to include in one year's incume more than the praceeds of the policy, it would be desirable to tax interest accruals on policies where the accumulated interest exceeds the surrender value.

23. In general, realization seems more likely to fall in a year of low income since loans or surrenders are more likely to be made in such periods, and endowments are lilsely to mature when the insured is retiring. In particular this would prubably be true when a part year return is filed as a consequence of death and the tax is computed as at present. If the tax were computed by making the exemptions and surtax brackets proportional to the fraction of the year covered by the return (as it should be), the pushing of income into higher brackets would be accentuated. It will be in a relatively small number of cases, however, that the interest earned on insurance reserves will be a sufficiently large fraction of the annual income to make a substantial difference through pushing the income into higher surtax brackets.

24. Under a spendings tax the treatment would be simple: the entire premium would be deductible and the entire amount of the proceeds would be included in receipts tu lie accounted for, any reinvestment of proceeds being in turn deductible.

25. See, for fuller discussion, Vichrey, Ar'traging of Incone for Incanc Tax Purpose's (1939) $47 \mathrm{~J}$. PoL. Ecox. 3\%9. The basic principle of the averaging plan there presented is that the total discounted value of tax payments uver a period shall be the same for all individuals whose total income for the period would have been the same had they been able to defer the realization of their income for tax purpuses to the end of the periud and earn interest on the taxes thus postponed. Under this plan there can be no gain or loss to the taxpayer through the shift of income from one year to another. It would te possible to permit all premiums to be deducted while requiring all benefits to be reported as income, or alternatively to have all interest reported in a single lump sum, without violence to the basic principles involved. 
surviving annuitants in a given age group of the residual capital of annuitants in that group who have died during the year. ${ }^{20}$

Under the present law, annuities are subject to tax to the extent of 3 per cent of the initial capital sum or other consideration paid for the annuity. But after a sum equal to the capital or other consideration paid for the annuity has been returned tax-free to the annuitant, the entire annuity becomes taxable. ${ }^{27}$

In principle the return of the capital of the annuitant obviously is not income; the interest paid on the residual capital clearly is; and although the premium or share in the distribution of the capital of dying anntitants

26. The following table shows how the annual payment breaks down into these components, and the amounts of the amnuity that would be taxable under various treatments:

Composition of Ammity Payments and Amomis Tarable.

Single premium straight life annuity of $\$ 100$ issued at age 40 .

1937 Standard Annuitants mortality table; 3 per cent interest.

Expenses: $7 / 2$ per cent of gross premium.

\begin{tabular}{|c|c|c|c|c|c|c|c|c|}
\hline & $\begin{array}{l}\text { Gross } \\
\text { Exper } \\
\text { Net p } \\
\text { Net }\end{array}$ & $\begin{array}{l}\text { emium } \\
\text { nium .... } \\
\text { e under }\end{array}$ & $t \operatorname{tax}$ & $\begin{array}{l}\ldots \ldots \\
\text { ations }\end{array}$ & . & $\cdots \cdots$ & $\begin{array}{r}\$ 2,11 \\
15 \\
1,95 \\
1,50\end{array}$ & \\
\hline & & Com & ition of $A$ & uity 1 & & Taxal & ortions & \\
\hline & & & & & & & Prese & an \\
\hline 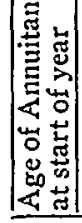 & 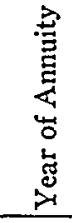 & 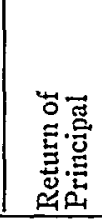 & 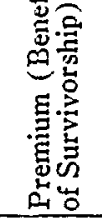 & 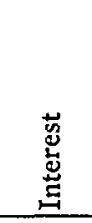 & 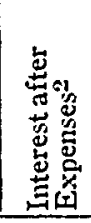 & 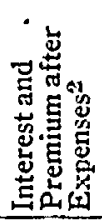 & 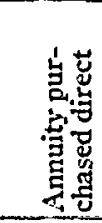 & 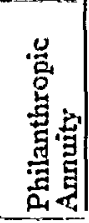 \\
\hline 40 & 1 & $\$ 32.63$ & $\$ 8.54$ & $\$ 58.83$ & $\ldots$ & .., & $\$ 63.32$ & $\$ 45.28$ \\
\hline 41 & 2 & 33.07 & 9.07 & 57.86 & & & 63.32 & 45.28 \\
\hline 42 & 3 & 33.50 & 9.61 & 56.89 & $\$ 15.27$ & $\$ 42.49$ & 63.32 & 45.28 \\
\hline 43 & 4 & 33.91 & 10.18 & 55.91 & 55.91 & 66.09 & 63.32 & $45.2 \mathrm{~g}$ \\
\hline 44 & 5 & 34.31 & 10.79 & 54.90 & 54.90 & 65.69 & 63.32 & 45.28 \\
\hline 49 & 10 & 35.96 & 14.28 & 49.76 & 49.76 & 64.04 & 63.32 & 45.28 \\
\hline 54 & 15 & 36.97 & 18.61 & 44.42 & 44.42 & 63.03 & 63.32 & $45.2 \mathrm{~g}$ \\
\hline 59 & 20 & 37.17 & 23.83 & 39.00 & 39.00 & 62.83 & 63.32 & 45.28 \\
\hline 64 & 25 & 36.43 & 29.92 & 33.65 & 33.65 & 63.57 & 63.32 & 45.28 \\
\hline 69 & 30 & 34.72 & 36.80 & 28.48 & 28.48 & 65.28 & 63.32 & 45.28 \\
\hline 73 & 34 & 32.67 & 42.75 & 24.58 & 24.58 & 67.33 & 63.32 & 84.94 \\
\hline 74 & 35 & 32.08 & 44.27 & 23.65 & 23.65 & 67.92 & 63.32 & 100.010 \\
\hline 79 & 40 & 28.69 & 52.05 & 18.26 & 18.26 & 70.31 & 63.32 & 100.00 \\
\hline 84 & 45 & 24.82 & 59.76 & 15.42 & 15.42 & 75.18 & 63.32 & 100.00 \\
\hline 89 & 50 & 20.87 & 66.98 & 12.15 & 12.15 & 79.13 & 63.32 & 100.00 \\
\hline 94 & 55 & 17.80 & 72.80 & 9.40 & 9.40 & 82.20 & 63.32 & 100.00 \\
\hline 97 & 58 & 17.87 & 74.27 & 7.86 & 7.86 & 82.13 & 80.07 & $100 .(10$ \\
\hline 99 & 60 & 17.68 & 75.50 & 6.82 & 6.82 & 82.32 & 100.00 & 100.00 \\
\hline 104 & 65 & 15.69 & 79.89 & 4.42 & 4.42 & 84.31 & 100.00 & 100.00 \\
\hline
\end{tabular}

1 The composition of the annuity will be the same at a given age of the annuitant regardless of when the annuity was taken out. This applies, however, only to stratight life annuities.

2 Considering the expenses as being concentrated in the first year.

27. U. S. Treas. Reg. 103, § 19.22 (b) (2) -2 . 
may be considered income by some, less discrimination results if this item is excluded. If, for example, a group of prospective anmuitants of the same age and with equal capital were to execute wills leaving their estates in equal shares to the survivors in the group and were tu spend each year what they would receive as an annuity from an insurance company. the amounts transferred to the others on the death of any of the gruup would certainly not be included in income. If the mortality of the group followed that expected by an insurance company and if there were no difference between the overhead expenses of the group and of the cumpany. the results obtained would be the same as though annuities had been purchased through the company. In general it would seem that if the premium is included in income, the loss incurred when an individual dies and his capital is forfeited should be deductible. But since at the death of the annuitant there is seldon any simple way of taking advantage of this deduction, the more equitable method is to ignore these gains and lusses.

Under the present law, only those living cunsiderably lunger than the average expectation of life will in most cases have their capital returned to them tax-free; many will have only a part of it and nune will have more than it so returned. The law would cause an individual who in the absence of any tax would be undecided whether to take out an annuity or manage his capital himself to choose the latter course." Including the premium

28. A further irregularity arises under the present law in the case of philanthrupie annuities, where the donor, typically a person of small capital and nu dependents, gives a sum to a philanthropic agency in return fur an annuity sumewhat smaller than could be obtained from an insurance company. The donor is thereby provided with an income ty replace that obtained from the investment of the amount given, and a purtion of the gift is made available for immediate philanthropy. Since the cunsideration paid fur such an annuity is indeterminate, the practice is to value such annuities, buth for the purpose of determining the amount to be considered a deductible gift in the current year's income tax return and for the purpose of determining the amount of the annuity to be tased in subsequent years, according to the table used for the valuatiun of life interests under the estate and gift taxes. This table is based on the Actuaries Combined Espreriense Mortality Table, representing British experience in the early part wi the nineteenth century, with 4 per cent interest. U. S. Treas. Reg. 79 . Art. $19(7)$ (1938 ed.). Sce als: id., table at $27-28$ : U. S. Treas. Reg. $105, \$ 81.10(1)(3)$. This tahle greatly wrerstaten the mortality to be expected under modern conditions, and cunsequently amuities are undervalued and remainders are overvalued. The diserepancy between the valuatiun of philanthropic annuities and those purchased from life insurance cumranies direetly is further increased by the lack of any loading for expenses in this table. The result is that the purchaser of a philanthropic annuity is able to ubtain the return of his eapital tas-iree somewhat more rapidly than the annuitant who deals directly with the insurance company and separately makes an outright giit of the difference in cust, since nut only is the amount of the deductible gift larger, but the taxable part uf the annuity is smaller. On the average the holders of philanthropic annuities will have sumewhat mure uf their capital returned tax-free before they die than those who huy the annuity directly and cuntribute the balance separately. While the treatment thus accurded invulves a slight discrimination, there is probably no real harm done. However, a mure cunsistent treatment wuld 
portion of the annuity in income would create a still greater bias in this direction, while the exclusion of the premium and the taxation of the interest portion alone would produce a tax with an approximately nettral effect on the same individual. ${ }^{20}$

Since annuities are fewer in number and usually involve larger amounts of interest than insurance policies, it would seem practicable to require insurance companies to inform annuitants each year of the amount of taxable interest, computed according to an approved modern mortality table at a specified rate, to be included in income. ${ }^{30}$

\section{Income Tax on Insurance Companies}

\section{Stock Fire and Casualty Companies}

Although questions concerning the treatment of insurance in the individual return can be resolved by reference to fairly well-defined principles of equity and non-discrimination, the treatment to be accorcled insurance companies under a corporation income tax depends in large measure upon the philosophy by which that tax is itself justified. At present, the corporation income tax in this country is no longer equivalent to a collection at source of individual income taxes, as it was in a rough way prior to 1934, or as it still is in a much more refined way in England. Nor is it to any extent a tax on the tax avoidance possibilities of the corporation, as are the largely hypothetical punitive surtaxes on personal holding companies and companies improperly accumulating surplus, and as the illfated undistributed profits tax was intended to be. About the only justification that can be presented for the corporation income tax in its present form is the purely opportunistic one that it is politically popular, productive of revenue, and not too difficult to administer.

be preferable and relatively easy to attain, for since there is nothing in the law concerning the table of mortality to be used, a more realistic table could be stbstituted by mere administrative regulation. The use of a more modern table would also be desirable for estate and gift tax purposes, and far more important. The same table is not necessarily appropriate for both purposes, however, since mortality among annuitants is probatbly lower than among the population as a whole or even among persons involved in estate and gift taxes.

29. The table in footnote 26 supra shows the amount of an annuity taxable under various methods.

30. This computation is relatively simple. For the ordinary life annuity all that is necessary is to multiply the amount of the annuity by a factor depending only on the age of the annuitant. The only reason for not putting a table of such factors in the law or regulations would be the prevalence of annuities with minimum term or refund features that must be specially evaluated. Other approximations have been suggested, but on the whole no gain in simplicity of administration sufficient to outweigh the departure from the theoretically proper treatment appears to be provided. See Warson, Income Tax on Annity Payments in Transactions of the Actunrial. Soc. of AM., May, 1940. 
But by whatever criterion the matter be judged, insurance is at this level also relatively lightly taxed. Insurance companies are divided for purposes of taxation into three groups: life insurance companies, taxed under sections 201-203; stock fire and casualty companies, taxed under section 204; and mutual fire and casualty companies, which, if not exempt under subsection 101 (11) are technically taxed under sectiun 207. In the taxation of stock fire and casualty companies. which is most like other corporation taxation, the tax base, with but minor modifications, has since 1921 been approximately net income as shown on the statements filed with the insurance commissioners of the various states. These commissioners are, however, interested primarily in preserving the solvency of companics and protecting policyholders, and so they tend to evaluate assets conservatively and to overstate liabilities. This bias yenerally results in an understatement of income in periods of growing business and in an uverstatement of income in periods of declining business. Among the important liability items are reserves for unearned premiums and for unpaid losses, additions to which may be deducted in computing net income. Conversely amounts released from these reserves when they are reduced are treated as income. . $^{31}$

The unearned premium reserve represents the liability of the company to service policies during the unexpired period for which premiums have been paid in advance. At present this reserve is in most cases arbitrarily fixed at one-half the gross premiums received on policies in effect at the end of the year. This figure would be approximately correct if policies were written uniformly throughout the year and if the expenses of servicing them were uniformly distributed over their lives. But actually up to 30 per cent or more of the gross premiums goes to pay for the immediate expenses of commissions and putting the business on the books. Thus of a $\$ 100$ premium on a one-year policy written July $1 . \$ 30$ is spent immediately for commissions and other underwriting expenses, and $\$ 35$ goes towards losses and adjustment expenses for the first six months. The balance which must be held as of December 31 to cover the losses and expenses of the final six months is $\$ 35$ rather than $\$ 50$ as computed by the formula. However, a company writing all its business in Decumber requires about $\$ 67$ per $\$ 100$ of premiuns to meet losses over an average of $23 / 24$ ths of the year, while one writing all its business in January needs only $\$ 3$, as compared with the $\$ 50$ allowed, to cover losses and expenses during the remaining period, which averages about two weelss.

A somewhat similar situation exists with respect tu the reserve for unpaid losses, which represents the liability of the insurance company for losses which have already occurred but which have nut yot been settled. The evaluation of this reserve necessarily involves some guesswurl al-

31. Sections 204(b) (5), 204(b)(6). 
though previous experience frequently furnishes a reasonable basis for estimation. As reported to state commissions, this reserve mist be at least a certain percentage of the premiums on the business, the percentage varying with the class of business. In practice percentages are tustally high enough so that the reserve arbitrarily set is much in excess of any amount shown by case analysis. And if analysis of reported claims on a case by case basis warrants, it must be even larger. 'The Bureatu of Internal Revenue has been upheld in insisting that the case basis be used when it shows a lower reserve than the percentage of premiums basis. It might be possible to go even further where the case basis reserve has in the past proved too high and reduce this reserve on the basis of experience on the business of previous years. However, in computing the income, it is necessary to avoid the temptation to consider developments between the end of the year when the reserve was set up and the time of the tax return's review. Such a procedure would go beyond the proper requirements of the concept of accrual of income and would be analogous to taxing as a capital gain not merely the excess of actual market valuc over cost but what the excess of market value should have been had certain later developments been foreseen. Nevertheless, methods of computing this reserve for unpaid losses will bear re-examination, even though the inllation of this reserve is neither as definite nor as easily corrected as the the carned premium reserve.

The overstatement of these two reserves causes a general postponement of income and an arbitrary concentration of income in certain years depending on fluctuations in the volume of business. For example, recent losses of business suffered by automobile liability companies because of gasoline and tire rationing have reduced their reserves and converted into taxable income profits previously concealed in them. Thus many of thesc companies have actually been subject to excess profits taxes in a time of reduced business. On the other hand, recent increases in the business and profits of employees' compensation companies have been hidden in increased reserves and these companies have for the time being been relatively free of tax. Were tax rates steady, this overstatement of liabilities would save the company a relatively small sum consisting of the interest on the tax so postponed. But when rates fluctuate and an excess profits tax is levied, the results may be extremely inequitable. The proper remedy is to require the reserves to be computed for tax purposes in a more realistic way, such as using the net premium after deducting underwriting expenses as a basis for computing the unearned premium reserve, and computing this reserve on the basis of the business of each month separately. At the time of transition companies should not, however, be allowed to use a reserve in the beginning of the year different from that at which they closed the preceding year, lest some income escape taxation entirely. On the other hand, the transition might well be spread over say 
five years since inclusion of income revealed hy the restatement of the reserves in the return of a single year would in itself involve inequities.

\section{Mutual Fire and Casualty Companics}

In the taxation of mutual fire and casualty companies the situation is somewhat more complex. Until 1942, almost all such companies were specifically exempt under section 101(11) of the Internal Revenue Citte. and even those not so exempt paid no tax. since they were allowed to deduct "premium deposits returned to their policyhulders" and "retained for the payment of losses, expenses and reinsurance reserves." 32 In mutual companies it is difficult to maintain that premiums could he retained for any other than the stated purposes. Moreuver, it was conceded by administrative ruling that in determining the amount of premiums su retained losses and expenses were to be considered as defrayed by investment income first and then by premium income. ${ }^{33}$ Thus no taxable incume remained except when investment income exceeded lusses and expenses, and this phenomenon occurred only in perpetual companies. ${ }^{34}$ They, therefore, paid all the tax reported as coming from mutual insurance companies other than life.

Stock companies had long protested against this virtual exempition of their competitors. and this alleged tax discrimination constituted amuther bone of contention in the acrimonious relatims between the two types of company. In an attempt to remedy this situation. the Treasury prounsed the changes contained in the House rersion of the $10+2$ Revenue Revision bill. ${ }^{3-}$ Under this version the exemption extended by section 101(11) would have been restricted to small companies, and the larger companies would have been taxed on what for most of them amounted to the sum of their investment income and their addition to unappurtioned surplus. adjusted to aroid orerlapping. This result would have been achieved by restricting the deduction of dividends to that part paid unt of premium income, it being considered for this purpose that incestment income is used before premium income to pay dividends. Instead of the deduction allowed for premiums retained to meet losses and expenses, a deduction would have been granted for additions to unearned premiums, unpaid

32. Section 207 (c) (3).

33. U. S. Treas. Reg. 103, § 19.207-6.

34. For example, a company might have income consisting of $\$ 1,000$ of premiums and $\$ 100$ of investment income, from which it could deduct lusses and expenses ui $\$ 230$, and premiums returned to policyholders (dividends) of say $\$ 250$, leaving $\$=0$ of inceme still not offset. Of the $\$ 800$ expenses, $\$ 100$ is considered paid from the investment ins mo, leaving $\$ 700$ to be defrayed from premiums. Deducting this $\$ 700$ of premium uned to pay losses and expenses and the $\$ 250$ of premiums returned from the $\$ 1000$ premiums received leaves $\$ 50$ of premiums retained to pay future lusses and expenses, and deducting this sum from the income leaves a net taxable income of zeru.

35. H. R. Rep. No. 2333, 77th Cong., 2d Sess. (1942) \$ 147. 
losses, and apportioned surplus. There would thereby have been exempted from tax any addition to surplus with respect to which there was an assurance that, subject to the prior claim of abnormal losses and expense's, it would be returned to that group of policyholders from which it was derived. On the other hand, any addition to surplus with respect to which no such assurance existed, and any amount not distributed within a reasonable time (tentatively set at five years) in accordance with the apportionment, would have been taxed.

The taxation of investment income was justified as a form of collection at the source of the tax on the income of the policyholder which was not but should have been included in his individual return. The addition to unapportioned surplus was to be taxed on the ground that it represented a transfer of income from one group of policyholders to future policyholders generally, or to an anonymous fund to which no indiviclual could acquire any enforceable or transferable claim. The exemption would have been retained for the smaller companies partly because they were largely farmers' organizations with strong influence in Congress and partly to avoid burdening the managers of these companies, who are frew quently part time or volunteer workers, with fairly complicated comptitations that would produce little revenue.

The larger mutual companies objected to this proposal because too drastic a change in their methods of operation would be required for them to take advantage of the apportioned surplus provisions, because the plan would bring demands from policyholders for larger dividends and because the proposal would generally hinder the accumulation of "free surplus" which they alleged to be essential for the aclequate protection of policyholders and the expansion of business. It was pointed out that certain non-dividend paying companies would pay a smaller tax than conparable dividend paying companies, since investment income, instead of becoming a taxable portion of the dividend, would perforce be offset against expenses or overlap the addition to surplus. And it was also asserted that the existing exemption should be continued, since mutual companies were "non-profit" organizations.

After much pulling and hauling among the representatives of the various types of mutual companies, the staff of the Joint Committee on Internal Revenue, the Senate Finance Committee, and the Treasury, there was finally incorporated in the Revenue Act of 1942 a section taxing most mutual insurance companies on either their net investment income at the corporation rates, or on the sum of their net premiums (after deduction of dividends) and gross investment income at 1 per cent, whichever method produced the larger tax. Exemptions were provided for small and medium sized companies with gross receipts less than $\$ 75,000$, or net investment income less than $\$ 3,000$, and special notch rates were created for companies just above these exemptions. Reciprocal insurers and inter- 
insurance exchanges were to be taxed only on their investment income, however, and such companies with less than $\$ 50,000$ investment income were exempted. ${ }^{36}$ Of the other companies, it was expected that only the perpetual and the "factory mutual" ones would normally be taxable on the investment income basis, the bulk of the companies being taxable on the gross income basis. There would seem to be no logical reason for this final result other than a desire to derive revenue from this source in a way which would bear at least some superficial resemblance to the corporation income tax and still not be too objectionahle to the companies.

\section{Life Insurance Companies}

The treatment of life insurance companies under the Revenue . Ict of 1942 is so peculiar that it can be understood only by reference to the historical development of these prorisions. Prior to 1921 the taxation of life insurance companies was a matter of considerable confusion. In 1921 attempts to simplify the application of the income tax to life insurance companies led to provisions taxing them on their investment income alone and of this income exempting a sum deemed necessary to maintain reserves at the levels required by state insurance regulations designed to assure payment of policies when due. The amount of this exemption was set at 4 per cent of the reserves "required by law." ${ }^{3 \pi}$ Representatives of the business in return for this favorable treatment agreed that their interest on government bonds should not be specifically extempt, since the exemption was considered covered by the reserve earnings deduction. This result was achieved by the devious method of permitting deduction of only the amount by which the 4 per cent of reserves exceeded the tax exempt interest. In 1928 the United States Supreme Court held that this device was merely a method of taxing exempt interest by indirection, and was therefore unconstitutional. ${ }^{38}$ As a result the insurance companies were accorded even more favorable treatment than that originally granted.

In 1932 Congress made an attempt to adjust the law to this decision. The House version of the revenue bill of that year proposed to reduce the

36. Pub. L. No. 753, §165.

37. The phrase "required by law" might ordinarily be thought to mean the minimum standard set up by state laws, particularly since the regulations state that "a company is permitted to make use of . . . the highest aggregate reserve called for by any state . . . in which it transacts business." Actually, while there is no state in which "Ameriean Experience" $3 \frac{1}{2}$ per cent preliminary term reserves would nut be acecptable, cumpanies have been allowed to use for income tax purposes whatever reserves were standing on their books, which in some cases are as much as 15 per cent higher (fur esample, the 3 per cent level premium), apparently on the ground that since the cunsent of the commissioner is ordinarily required before a change in the reserve standard may be made, this amounts to being "required by law."

38. National Life Insurance Company v. United States, 277 U. S. SuS (1923) (Justices Brandeis, Holmes, and Stone dissenting). 
reserve earnings allowance from 4 per cent to $3 \frac{1}{2}$ per cent of the reserves, ${ }^{39}$ and the bill as reported to the Senate by the Senate Finance Committee proposed to use a percentage equal to the rate of interest assumed by each company in computing its reserve. ${ }^{40}$ In the course of the debates on these two proposals it was argued somewhat confusedly that the use of a fixed percentage would unduly favor companies using 3 per cent in computing their reserves (largely the mutual companies) and that the use of rates assumed by the companies would unduly favor those using $3 \frac{1}{2}$ per cent (largely the stock companies, most of which were small companies). Although the actual examples posed were of doubtful comparability and failed to prove these contentions, both points were well taken. A company may within limits select the rate of interest it wishes to use in computing the reserve without altering to any substantial extent the significant terms of the policy; and the higher the rate chosen, the smaller the reserve. The difference in the reserve for a company with a typical distribution of business is considerably less than in inverse proportion to the rate of interest used in computing them, so that $31 / 2$ per cent of a reserve computed at $3 \mathrm{I} / 2$ per cent is somewhat more than 3 per cent of a reserve computed at 3 per cent. Use of a fixed rate, however, produces less discrimination in most cases than the use of an assumed rate. It was also argued that the companies were entitled to deduct the actual interest added to the reserve. This idea was somewhat irrelevant, however, in view of the arbitrary way in which the interest factor is chosen and the absence of any close relation between the significant terms of the policy and the interest assumed in computing the reserves.

In the bill as finally passed, Congress apparently gave the companies the benefit of the very considerable doubt still in their minds and provided for the use of a fixed 33/4 per cent of the reserves except for the small amount of business still on the books at rates of 4 per cent or more on which 4 per cent was allowed. ${ }^{41}$ The final product was thus more lenient than either of the original proposals. Nothing was done to remedy directly the overlapping of the reserve earnings allowance and the deduction of tax exempt interest.

This change did not help for long, for with the general fall of interest rates and increasingly heavy investments by insurance companies in government bonds, their taxable income diminished rapidly. By 1939 few companies had paid any tax for several years, and the bulk of the tax was being paid by two small companies that had invested heavily in mortgages yielding a relatively high rate of return. When the revenue program for 1942 came up for consideration, the Treasury at first proposed substantially the following changes:

39. H. R. Rep. No. 708, 72d Cong., 1st Sess. (1932) 25.

40. Sen. Rep. No. 665, 72d Cong., 1st Sess. (1932) 35.

41. Revenue Act of $1932, \S 203(2)$. 
1. The double deduction of tax exempt interest was to be eliminated by prorating this government interest between reserves and other funds, and reducing the reserve earnings allowance by the amount of exempt interest allocated to reserves. It was expected that the change in the climate of opinion concerning tax exempt interest and the fact that a part of the tax exempt interest would still be fully and separately deductible would prevent a repetition of the National Life case.

2. In order to avoid discrimination between companies using different rates of interest in computing reserves, a formula for computing the reserve earnings allowance was suggested by which the rate of interest used would be a weighted average of a fixed rate of $3 / 4$ per cent ( $a$ rough overall average of the rates then in use) and the actual rate assumed in computing the reserve. The weights were to be adjusted so that the allowance would be the same for companies with a typical distribution of business regardless of the rate of interest assumed in computing the reserve.

3. Companies computing their reserves on the less stringent "preliminary term" basis, which gives a smaller reserve than the more usual "level net premium" basis, ${ }^{42}$ would be allowed for tax purposes to adjust such reserves upward by 7 per cent.

4. The cancellable accident and health business of life insurance companies was to be segregated and taxed separately in accordance with the rules for casualty companies. Non-cancellable accident and health insurance ${ }^{43}$ however, was to be treated like life insurance. ${ }^{14}$

The insurance companies through their representatives were willing to pay the aggregate amount of taxes so levied, but objected to the way in which the tax burden was distributed among the various companies. After negotiation among themselves, they countered with the proposition that the total amount of tax determined according to the Treasury proposal be distributed among the companies in proportion to their net in-

42. The level premium method assumes that the net amount received by the company after paying expenses will be the same throughout the life of the policy. The preliminary term method allows for the initial expenses of writing the policy by assuming that the amount available after expenses the first year will be somewhat smaller than for later years: for most policies the amount is set as the premium for term insurance for one year. The latter method is more realistic, but is used chiefly by the smaller companies, most of the larger companies holding to the level premium method.

43. Non-cancellable accident and health insurance is like life insurance in that the company must continue the policy in force as long as the premiums are paid, while a cancellable policy cannot be renewed unless the company is willing, and may ordinarily be cancelled on brief notice by refund of an appropriate part of the advance premium. Such policies usually require the accumulation of a substantial reserve in addition to the unearned premium reserve, and are subject to adverse selection.

44. Other changes were suggested which had to do with the treatment of burial companies, assessment life insurance companies, and foreign insurance companies, and with the limitation on the deduction of investment expenses. 
vestment income. ${ }^{45}$ The true brazenness of this proposal can be appreciated by picturing the United States Chamber of Commerce and the National Association of Manufacturers getting together and suggesting that the Treasury compute the amount it expects to receive from the corporation income tax and then distribute this total levy in proportion to the total assets, payroll, or gross receipts of the various corporations, without reference to their rate of profit or whether in fact there was any profit at all. Naturally a substantial majority of companies would favor such a proposal, even though it would increase the taxes of some, for it would result in a tax which could readily be shifted to consumers or wageearners. Although the Treasury proposal would not necessarily have taxed most heavily those companies making the largest total profits, it would have at least taxed more heavily those receiving higher rates of return on investments or having larger surpluses. Thus there was under it a greater likelihood that the burden would not be passed on to policylolders. Moreover, it represented a logical improvement on a method of taxation which had been in operation for twenty years. Nevertheless the Treasury, faced with an outwardly united front on the part of the industry and a restive Congress, acceded to the unique and unprecedented proposal of the life insurance companies; and the Revenue Act of 1942 put this proposal into effect by lumping all the policy liability deductions together in a single deduction to be computed by applying a flat percentage, to be determined annually by the Secretary of the Treasury, to the net investment income. This percentage is to be an estimate of what the ratio of the aggregate policy liability deductions under the original Treasury proposal to the aggregate net investment income for all companies would have been for the previous year. ${ }^{46}$ For 1942, for example, the percentage has been determined to be 93 per cent. ${ }^{47}$ The net effect of this rigmarole is to tax these companies at the corporation income tax rates on a base equal to 7 per cent of their net investment income, with this percentage varying from year to year. In spite of the fact that the weighted average rate of interest and the other refinements clevised by the Treasury to avoid discrimination were robbed of their raison d'ctr' by this arbitrary spreading of the tax burden, the formula and the adjustments were retained in the law as vestigial remnants of a hopeful attempt. For the immediate purposes of assessing the tax this section of the law as it now stands is the prime example of pointless complexity in the income tax law.

45. The well-organized character of the life insurance industry is well attested to by the degree of outward unity shown in backing this proposal. Stock and mutual companies appeared to be in close agreement, in sharp contrast to the acrimonious relations between the stock and mutual casualty companies, where representatives of the two types of company would hardly meet together in the same room.

46. Pub. L. No. 753, §163.

47. T. D. 5188, 1942-2 CuMr. Buls. 151. 
The proposal to segregate cancellable accident and health insurance was also opposed on the ground that any attempt to allocate expenses between the two types of business would lend to endless dispute and litigation. As a substitute, it was proposed to tax such business on investment income only, but without any allowance for interest on reserves. Such a result was to be accomplished by adding to the tax base as otherwise computed, $3 \frac{1}{4}$ per cent of the reserves on such insurance, this figure being equivalent to the amount that would be deducted through the application of the percentage declared by the Secretary to the total net investment income. Even this principle was not followed consistently, however, for at the suggestion of representatives of the industry and in order to prevent companies which write on a predominantly weekly and munthly premium basis from getting away with a small tax because of the luw reserves on this type of business, it was provided that the amuunt added should not be less than $31 / 4$ per cent of 25 per cent of the annual premiums. ${ }^{48}$

The change in the incidence of the tax burden brought about by this change in the form of tax is not completely clear. In the case of stocl: companies, it would seem that the long run result of the imposition of this tax would be comparable to a reduction of 0.1 per cent in the rate of return on investments, and that the premiums on new policies would be calculated on a lower interest assumption and henee would be increased. As all companies pay comparable taxes on similar volume of business. regardless of profit, there will be no competitive reason why this increase cannot be made. Thus stockholders in life insurance companies will continue to be almost completely free from any corporation income tax burden, except insofar as they are unable to shift the burden to nun-participating policyholders.

In the case of mutual companies it is difficult to tell what the effect of the tax will be on the accumulation of surplus and hence to what extent the burden will fall on the policyholders and to what extent upon this anonymous fund. On the whole it appears probable that they will in large measure follow the stock companies in passing on this tax to the policyholders, and particularly to new policyholders.

In view of the much more general disparity in taxation between incorporated and unincorporated business, the situation with regard to life insurance is not too intolerable. In fact, were insurance proceeds adequately taxed to the policyholder, it would be possible to argue for more favorable treatment for insurance companies on the ground that those who insure should not be subjected to heavier taxation, even indirectly, than those who do not. However, should any serious attempt be made to reintegrate the corporation income tax with the individual income tax,

48. Pub. L. No. 753, $\$ 202$. 
whether in the form of collection at source of part of the income tax or in the form of some sort of compensatory tax on undistributed profits designed to offset the avoidance possible through the ploughing back of earnings, a more effective method for taxing insurance companies will have to be devised.

The problem would be particularly acute with respect to undistributed profits. Even at present, investment in insurance companies is partict1larly profitable for those with large incomes. Insurance companies typically plough back large fractions of their earnings, in fact they are encouraged and even almost compelled to do so by the regulations of state insurance commissions. And no matter to what extent this ploughing back of earnings is carried, no insurance company could be charged with improper accumulation of surplus and assessed under the penalty provisions of section 102 with any likelihood of success, for the company would always have available the very appealing defense that this accumulation was for the greater protection of the policyholders. As a matter of fact, insurance companies were specifically exempt from the provisions of the undistributed profits tax under the Revenue Act of $1936 .{ }^{40}$

The principal difficulty in determining either the income or the undistributed profits of a stock life insurance company is the fact that the liability represented by the reserve bulks large in relation to the income and will only be liquidated over a very long period of time. Slight differences well within the limits of reason in the evaluation of this liability will produce relatively large differences in the income reported. As has been noted before, the methods now used to evaluate this liability on the books of the companies are far from realistic, being based on obsolete mortality tables, fictitious future premiums, and an unrealistic allocation of expenses over the life of the policy. Probably no reasonably uniform and realistic evaluation of the income or undistributed profits of such companies would be possible without recomputing the reserve, preferably using the gross premiums, the actual renewal expenses of the company, uniform statutory modern mortality tables, and a stipulated rate of interest. Such valuation would require drastic changes in methods from the present net premium method, since tables of reserve values would be so cumbersome as to be almost useless. Even if the net premium method were accepted for the sake of simplicity, revaluation would be a task out of all proportion to the amount of tax involved, unless the proposed tax valuation could be adopted as the standard for regulatory purposes as well. In the case of participating stock companies there would be the further complication, at least under the gross premium method, of evaluating the liability of the company for the payment of dividends to policyholders as future developments warrant under policy provisions which are not always precise.

49. Revenue Act of $1936, \S 14$ (d) (3). 
In the case of an insurance company, whether life or casualty, which is truly mutual in the sense that all its funds are kept apportioned to the various groups of policyholders so that in effect no one group profits at the expense of any other group, except through that sharing of risk that is the essence of insurance, there is no problem other than to see that the entire net investment income is taxed either to the company or to its policyholders. But while in casualty insurance it may be possible to operate in such a purely mutual fashion, as the interinsurance exchanges and the reciprocal underwriters actually do, ${ }^{50}$ in life insurance the fact that the policy is non-cancellable and subject therefore to adverse selection of terminations by the policyholder makes this practically impossible." Among

50. In such organizations, which usually operate through an attorney-in-fact who customarily takes a fixed percentage of premiums to cover expenses and his compensation, any savings realized in any year are immediately credited pro rata to the policyholders of that year, each of whom may have returned to him upon leaving the ascociation any of this accumulated savings that has not been distributed previously. There is thus no unapportioned surplus nor any transfer from one group of policyliolders to another.

51. The difficulty may be illustrated by the following example in which, for simplicity, interest and overhead expenses will be ignored. Suppose a group of 100 individuals form a mutual insurance company, each being insured for $\$ 1,000$. They are all at the time first class risks and each pays a premium of $\$ 500$ to cover the first period. During this period 20 die and are paid $\$ 20,000$ in benefits, so that $\$ 30,000$ remains in the reserve fund. The remaining 80 pay another premium of $\$ 500$ for the sceond period, during which 60 die and are paid $\$ 60,000$ in benefits, leaving $\$ 10,000$ in the reserve at the end of the second period. In the third period the remaining 20 pay a third $\$ \$ 00$ premium, producing a total fund of $\$ 20,000$ which is just sufficient to pay the death bencfit to these 20 when they die during the third period. The $\$ 500$ premium is thus just suffcient to provide the required benefits.

Suppose further, however, that at the end of the first period the remaining $\$ 0$ lives are no longer on a par as regards health, but that there are two groups, one of 50 persons in impaired health, of whom 45 , or 90 per cent may be expected to die during the next period and only 5 survive to the third period, while the remaining 30 are still first class risks of whom 15, or 50 per cent will survive to the third peried and only 15 die during the second period. Suppose also that about one-third of each of these groups of policyholders find their circumstances so changed that either beeause they no longer have a closely dependent beneficiary or find the burden of premiums too heavy, they no longer wish to continue their insurance. However, of the 17 policyholders in poor health that have reason to discontinue their policies, 7 consider that since they have a good chance of obtaining more from death benefits than the cost to them in premiums and whatever surrender value they could obtain, they may profitably continue their insurance as a speculation, even though the premium may be a little dificult to pay or the beneficiary a little remote. Thus actually only 10 of the impaired lives withdraw, while all 10 of the insured in good health that have reason to withdraw will do so. The question is what should be paid to these withdrawing policyholders as a surrender value.

If we merely divide the $\$ 30,000$ reserve equally among the $\$ 0$ policyholders and give each withdrawing policyholder $\$ 375$, the balance remaining will be insufficient to maintain solvency. Of the 40 continuing impaired lives, 90 per cent or 36 will die in the second period, and of the 20 remaining first class lives 10 would be expected to die in 
life insurance companies, therefore, a certain amount of unapportioned surplus is amost inevitable. But mutual insurance companies, both life and fire and casualty, commonly accumulate unapportioned surpluses which are considerably greater than the nature of the insurance business requires. Sometimes these accumulations merely provide a moderate

the second period, leaving a total of 14 to survive until the third period. Premium receipts are accordingly $\$ 50,000$ the first period, $\$ 30,000$ the second, and $\$ 7,000$ the third, a total of $\$ 87,000$. Benefits payable to the 80 who do not surrender total $\$ 40,000$, and the $\$ 375$ surrender values amount to $\$ 7,500$, a total of $\$ 500$ more than is available.

If solvency is to be preserved, therefore, only $\$ 7,000$ can be distributed to surrendering policyholders, or $\$ 350$ each. In practice it would be a matter of guesswork how much less than the aliquot share of the reserve should be distributed to allow for this adverse selection. But this is still not an adequate solution. If $\$ 350$ were offered as a strrender value to the first class lives that still have reason to continue their insurance, they would find it to their advantage to withdraw and set up a new company in which they will not be burdened with the impaired lives. If ten of the first class lives set up a new company in which the first period premiums (corresponding to the second period of the old company) are $\$ 750$, and the second period premiums are $\$ 500$, they will have sufficient funds to pay $\$ 1,000$ death benefits to the five dying the first year and the five dying the second year. If the $\$ 350$ surrender value is applied to the first year premium the net outlay is reduced to $\$ 400$, a reduction of $\$ 100$ as compared to what they would have to pay if they stayed with the old company. Thus in theory, at least, the surrender value offered the first class lives cannot be greater than $\$ 250$ without offering these policyholders an incentive to leave the company and set up a new one.

If the surrender value is limited to $\$ 250$, and thus only $\$ 5,000$ paid out, there will remain $\$ 2,000$ that will not be required to meet the obligations of the company. Equitably this belongs to the ten surrendering policyholders with impaired lives, as this $\$ 200$ cach plus the $\$ 250$ surrender value would be just sufficient together with a $\$ 500$ premium cach period to pay $\$ 1,000$ death benefits should these policyholders form a new company and insure again separately. This sum could of course only be paid out after a physical examination, a quite impractical procedure, both because of the expense and because of the uncertainty as to the proper monetary value to be placed on such impairment of health as is shown. Moreover, the need for it is slight, since the surrendering policyholder is presumably less in need of insurance and may no longer have an insurable interest in his life which would call for an indemnity for a reduction in life expectancy.

In practice, because of inertia and the overhead costs involved in the writing of insurance, the question is not as critical, and surrender values can be set considerably higher than the amount corresponding to the $\$ 250$ in this example without causing an undue increase in the degree of adverse selection. However, there will usually remain an element of gain from lapses and surrenders which may be considered a source of taxable profit to the remaining policyholders. The measurement of this profit for tax purposes, however, would involve difficulties out of proportion to the revenue involved.

Another form of adverse selection is the concentration of surrenders in years of reduced income when security markets are likely to be depressed, thus causing the company to sell securities under unfavorable conditions or to miss investment opportunities. This problem can be adequately dealt with, however, through the device of the termination dividend, which can be varied according to the state of the market, payable at death, or upon maturity or surrender of the policy. Up to the present only the Metropolitan Life Insurance Company has made use of this device, so far as the writer knows, and even here it does not seem to have been used primarily for this particular purpose. 
special contingency fund, but often they appear to be used primarily as a means by which the directors may stimulate the growth of their business, expand their assets, and enhance their own prestige and economic influence. In some cases these unapportioned surpluses have reached almost fantastic levels, amounting in some fire and casualty companies to several times the annual premiums. ${ }^{\text {t2 }}$

It may well be considered proper to tax the additions to such unapportioned surplus of mutual insurance companies on the ground that they are transfers from one group of policyholders to another perhaps yet uninsured group, or at least that these additions constitute payments into a fund which may grow indefinitely without ascertainable beneficiaries. To the extent that the final incidence of the tax would actually be upon the unapportioned surplus, the tax might be as nearly burdensomeless as any tax it is possible to devise. But an attempt to lery a tax on such a basis would be considerably at variance with the principles on which the rest of the income tax is based, and the tax would be more nearly amalogous to an estate tax than to an income tax. In the case of life insurance companies particularly there would be difficulty in determining just what surplus was apportioned and what was not.

The logical application of the corporation income tax to insurance companies is thus an extremely difficult task. Perhaps there is no completely satisfactory solution short of either a shift to the spendings tax or to the use of comprehensive averaging. A complete shift to a spendings tax would make a corporation income tax unnecessary insufar as any interrelation with individual taxation is concerned, since accruals on investments do not enter into the computation of spendings. For the same reason the treatment of insurance proceeds would also be simpler. Comprehensive averaging of income as applied to the individual can be so designed that it is a matter of indifference when income is reported $:^{50}$ undistributed profits are then no problem, since the proper tax will be collected when the profits are eventually distributed or the equity of the shareholder evaluated at the end of the averaging period. Hence no special tax on corporate undistributed profits would be necessary as a compensatory measure. The application of comprehensive averaging to corporations likewise makes it a matter of indifference in what year

52. While on the average, fire companies have available assets on hand to mcet five or six normal years' losses, there were in 1939 two muderately large companies with assets available to cover sixty years of normal losses, and 22 other companies with assets for from ten to forty years' losses. Ten of these companies, including one of the sisty year companies, paid no dividends to policyholders; how these funds can ever be distributed to anyone is a mystery. Similar cases, though not so striking, occur in cacuslty insurance. In life insurance it is difficult to reach any conclusion from the publishcd figures because of the complicated nature of dividend formulae, but quite possibly analogotis cases could be found.

53. See note 25 supra. 
income is reported; the vagaries of the reserves would therefore be of no concern, and if a corporation tax is to be continued, either as a tax on business or otherwise, this method would probably be simpler than any attempt at revision of reserves. But both the complete shift to the spendings tax and the adoption of comprehensive averaging involve such an alteration of the entire income tax structure as to be only remote possibilities; and for the immediate future we must look to other less satisfactory remedies.

\section{Suggestions}

The Revenue Act of 1942 made more changes in the taxation of insurance than had been made in many years; yet this phase of taxation is still in a far from satisfactory state. Nothing of any practical effect was done about the treatment of insurance in the income tax return of the individual. The amendments to the corporation income tax on insurance companies slightly reduced the disparity between the taxes paid by these companies and those paid by other corporations, but the method of assessment is now further, if anything, from a logically defensible basis than it was before.

While it may be too much to expect that the subject will be reopened immediately, the following are some initial steps which might be taken to improve the taxation of insurance without requiring too drastic changes in the basic tax structure:

1. Life insurance companies should be required to report to the policyholder the amount of interest earned less expenses incurred whenever the policy terminates (or previously, if the value of the policy falls below the amount of interest because of loans, or if the accumulated interest grows to exceed the value of the policy); and the policyholder should be required to include this amount in his income.

2. Losses from fire, storm, theft, or other casualty to non-business property should be allowed for, if at all, by a tax credit at a rate equal to the sum of the normal tax and the first bracket surtax rates.

3. Accident and health insurance premiums should be deductible and the proceeds from such insurance and employees' compensation benefits should be included in gross income. The allowance for abnormal medical expenses should be continued but possibly only as a tax credit at a rate equal to the sum of the normal tax and first bracket surtax rates. If this credit form of allowance is adopted, the present maximum limit on the allowance may be increased or removed entirely.

4. Those purchasing insurance other than life for more than one year in advance (including holders of perpetual-type policies) should be required to include in their income the interest on the premium or unconsumed portion thereof at a specified rate. 
5. Annuitants should be required to include in their income only the interest earned as reported to them by the insurance companies, calculated according to an approved modern mortality table and a specified rate of interest.

6. Philanthropic annuities (and life estates and reversions under the estate and gift taxes) should be valued according to modern mortality tables, both for determining the amount to be deducted as a charitable contribution and, if the suggestion in item $\mathbf{5}$ is not adopted, for determining the amount of the annuity to be taxed.

7. If the corporation income tax is continued in its present form, the unearned premium reserves of stock casualty and fire insurance companies should be computed on a net premium basis and for the business of each month separately. The transition between the old and new methods of computing the reserve may be spread over five years, using at the end of the first year a reserve equal to 20 per cent of the reserve on the new basis and 80 per cent of the reserve on the old, and so on.

8. If the present form of corporation income tax is continued, an attempt should be made to tax stock life insurance companies on their income from all sources, even though doing so might mean accepting a highly artificial valuation of their reserves and setting up a seeming discrimination in favor of mutual companies. At least in the long run errors in evaluating the reserve liability will tend to cancel out. 